\title{
The Global Boundary Stratotype Section and Point for the base of the Turonian Stage of the Cretaceous: Pueblo, Colorado, U.S.A.
}

\author{
1 Geological Collections, Oxford University Museum of Natural History, Parks Road, Oxford OX1 3PW, United Kingdom \\ 2 Institute of Geology of the University of Warsaw, Al. Zwirki I Wigury 93, 02-089 Warszawa, Poland \\ 370 Estes Street, Lakewood, Colorado 80226, USA
}

\begin{abstract}
Following the recommendation of the International Commission on Stratigraphy (16 votes Yes [94\%], 1 abstention, 2 votes not received), the Global boundary Stratotype Section and Point (GSSP) for the base of the Turonian Stage of the Cretaceous System is defined as the base of bed 86 of the Bridge Creek Limestone Member of the Greenhorn Limestone Formation at the western end of the Denver and Rio Grande Railroad cut near the north boundary of the Pueblo Reservoir State Park Recreation Area, west of Pueblo, Colorado, USA. This GSSP horizon is also exposed and protected in the adjacent state recreation area. It coincides with the first occurrence of the ammonite Watinoceras devonense, is in the middle of a global positive excursion in Carbon-13 isotopes, and is bracketed by widespread bentonites that have yielded ages of 93 to $93.5 \mathrm{Ma}$.
\end{abstract}

\section{Introduction}

The present document defining a Global boundary Stratotype Section and Point (GSSP) for the base of the Turonian Stage of the Upper Cretaceous arises from the recommendations of the Turonian Working Group of the Subcommission on Cretaceous Stratigraphy at its meetings during the Second International Symposium on Cretaceous Stage Boundaries held in Brussels from September 8-16 1995. A report of the conclusions of the Turonian Working Party was provided by Bengtson (compiler) (1996). The proposal was subsequently submitted to the International Commission on Stratigraphy, which voted Yes 16 votes (94\%), with one abstention and two votes not received. The International Union of Geological Sciences was requested to ratify this decision; the proposal was finally ratified in September 2003.

\section{Historical Background}

When Alcide d'Orbigny began to divide the Upper Cretaceous into stages, he at first recognized only two, the Turonian below, and the Senonian above (1843, pp. 403-406). With respect to the Turonian, his words are: “je propose de designer à l'avenir l'étage qui m'occupe sous le nom de terrain TURONIEN, de la ville de Tours (Turones) ou de la Touraine (Turonia), situées sur ces terrains" (1842, p. 404), defining the Turonian as equivalent to the Craie Chloritée, Craie tuffeau, Glauconie crayeuse, Grès Vert Supérieur etc., and taking the name from Touraine (Roman Turonia). Six years later he realised that two distinct ammonite and rudistid faunas were present and restricted the term to beds corresponding to his third zone of rudists, yielding "Ammonites Lewesiensis, peramplus, Vielbancii, Woollgari, Fleuriausianus, Deverianus" etc. (d'Orbigny, 1851, p.270 ), stating "le plus beau type Côtier était très prononcé dans tout la Touraine".

In the second volume of the Prodrome (1850) d'Origny listed 809 species as characteristic of the Cenomanian and 366 as characteristic of the Turonian. In the Cours Elementaire (d'Orbigny, 1852) there is the most complete statement of the Cenomanian and Turonian stages. The origin of the names is explained, faunal characteristics are defined, and type areas are indicated, as are other regions or successions where rocks of comparable age are known. Most significantly, the area between Saumur and Montrichard is stated to be the type area. Although d'Orbigny did not define the CenomanianTuronian boundary in unmistakable terms and there are conflicting data in the Prodrome and Cours Elementaire, he regarded Metoicoceras [Ammonites] geslinianum, Actinocamax plenus (Blainville) (=Belemnitella vera d'Orbigny non Miller) and Terebratella carantonensis as Cenomanian, and Lewesiceras [Ammonites] peramplus (Mantell), L. [Ammonites] lewesiense Mantell and Inoceramus labiatus (=Inoceramus problematicus d'Orbigny) as Turonian.

The definition of the boundary between Cenomanian and Turonian Stages should, as far as possible, follow d'Orbigny's views. Wright \& Kennedy (1981, p.126) reviewed this historical evidence, in the context of an ammonite zonal scheme as follows:

\begin{tabular}{c|l}
\hline LOWER TURONIAN & $\begin{array}{l}\text { Mammites nodosoides Zone } \\
\text { Watinoceras coloradoense Zone }\end{array}$ \\
\hline $\begin{array}{c}\text { UPPER CENOMANIAN } \\
\text { (part) }\end{array}$ & $\begin{array}{l}\text { Neocardioceras juddii Zone } \\
\text { Metoicoceras geslinianum Zone }\end{array}$ \\
\hline
\end{tabular}

They concluded that although d'Orbigny did not define the Cenomanian-Turonian boundary in unmistakable terms, and although there are conflicting data in the Prodrome (d'Orbigny, 1850) and Cours Elementaire (d'Orbigny, 1852) (conflicts stressed by Hancock, 1984, p.124), there is an argument that the Metoicoceras geslinianum Zone as used by Wright \& Kennedy is Cenomanian and the Mammites nodosoides Zone as used by Wright \& Kennedy is Turonian (other, earlier definitions have regarded the nodosoides Zone as including horizons as low as geslinianum Zone).

The interval spanning geslinianum to nodosoides Zones of Wright \& Kennedy encompasses most of the proposed markers noted by Birkelund et al. (1984) in their summary following the 1983 Copenhagen Meeting, which were:

(a) Base of the Metoicoceras geslinianum ammonite Zone, or slightly later appearance of the ammonite Euomphaloceras septemseriatum.

\footnotetext{
* With contributions by P. Dodsworth, W.P. Elder, A.S. Gale, G.R. Scott, J.M. Hancock, S. Voigt and J.I. Kirkland
} 
(b) Base of the Pseudaspidoceras flexuosum ammonite Zone (or better the appearance of some vascoceratid ammonite, possibly Vascoceras proprium).

(c) "The appearance of the [ammonite] Assemblage Zone of Watinoceras coloradoense is the definition that has been most used by ammonite workers in Europe during the last few years. This level is close to proposal (b) above. However, the nominate subspecies is absent in Europe, and the base of the zone is drawn at a lower level than the base of the zone of the same name in the USA (see Cobban this volume), this lower level probably corresponds to the base of the P. flexuosum Zone". (Birkelund et al, 1984, p. 12).

(d) Definition on the basis of the Mytiloides inoceramid bivalve lineage.

(e) The appearance of a flood of Mytiloides at the base of the assemblage zone of Mammites nodosoides.

(f) Appearance of the coccolith Quadrum gartneri in the ammonite zone of Neocardioceras juddii.

(g) The extinction of the planktic foraminiferan genus Rotalipora in the Metoicoceras geslinianum Zone.

(h) The appearance of the planktic foraminifer Whiteinella archaeocretacea.

(i) The appearance of the distinctive Turonian planktic foraminifer Praeglobotruncana helvetica.

Their only mention of anoxia at this level is the observation that "the distinctive anoxic event of Schlanger \& Jenkyns (1976) has recently been shown by Hart \& Bigg (1981) to fall within the W. archaeocretacea Zone".

The conclusion of Birkelund et al. was as follows:

"Conclusion

Boundary level: The boundary at the base of the Pseudaspidoceras flexuosum Zone gained some support. In the present volume it is recommended in papers by Cobban and by Kennedy. However, P. flexuosum has a restricted geographical distribution.

Important support for that boundary is the widespread appearance of early Mytiloides as represented by $\mathrm{M}$. opalensis sensu Kauffman at the same level, an event which can be traced in both Tethyan and Boreal regions (recommended by Hancock, this volume).

The appearance of Quadrum gartneri immediately below, in the Neocardioceras juddii Zone and the extinction of Rotalipora in the Metoicoceras geslinianum Zone further below are world-wide markers."

The Copenhagen Meeting stimulated work on the CenomanianTuronian boundary, such that it is now recognised as an interval in which a major oceanic anoxic event occurred, and during which a phase of mass extinction is claimed. Work on ammonite and inoceramid bivalve faunas in the U.S. Western Interior has produced great refinement of the ammonite and inoceramid zonation across the boundary interval, while biostratigraphic, isotopic, geochemical and radiometric analysis on the section at Pueblo in Colorado (Figure 1) and its correlatives led to the proposal of the section as a candidate stratotype for the Cenomanian-Turonian boundary.

\section{The Global boundary Stratotype Section and Point for the base of the Turonian Stage}

The section at Pueblo (Figures 1, 2; Tables 1,2) was known to Stanton (1894), was mapped by Scott $(1964,1970)$ and ammonite faunas documented by Cobban \& Scott (1973), Cobban (1985), Elder (1985), Kennedy \& Cobban (1991) and Kennedy et al. (1999, 2000). Inoceramid bivalves are documented by Kennedy \& Cobban (1991), Elder (1991) and Walaszczyk \& Cobban in Kennedy et al., 2000; planktic foraminifera by Eicher \& Diner (1985), Leckie (1985),
Keller \& Pardo (2004), and Keller et al. (2004); calcareous nannofossils by Watkins (1985) and Bralower (1988); dinoflagellates by Dodsworth (2000); stable isotopes by Pratt (1981, 1983, 1984, 1985), Pratt et al. (1993), Pratt \& Threlkeld, (1984), Keller \&Pardo (2004), Keller et al. (2004), and Gale et al. (2005); iridium anomalies by Orth et al. (1988); and numerical dating of bentonites in correlative sections by Obradovich (1993) and Kowallis et al. (1995). Elder

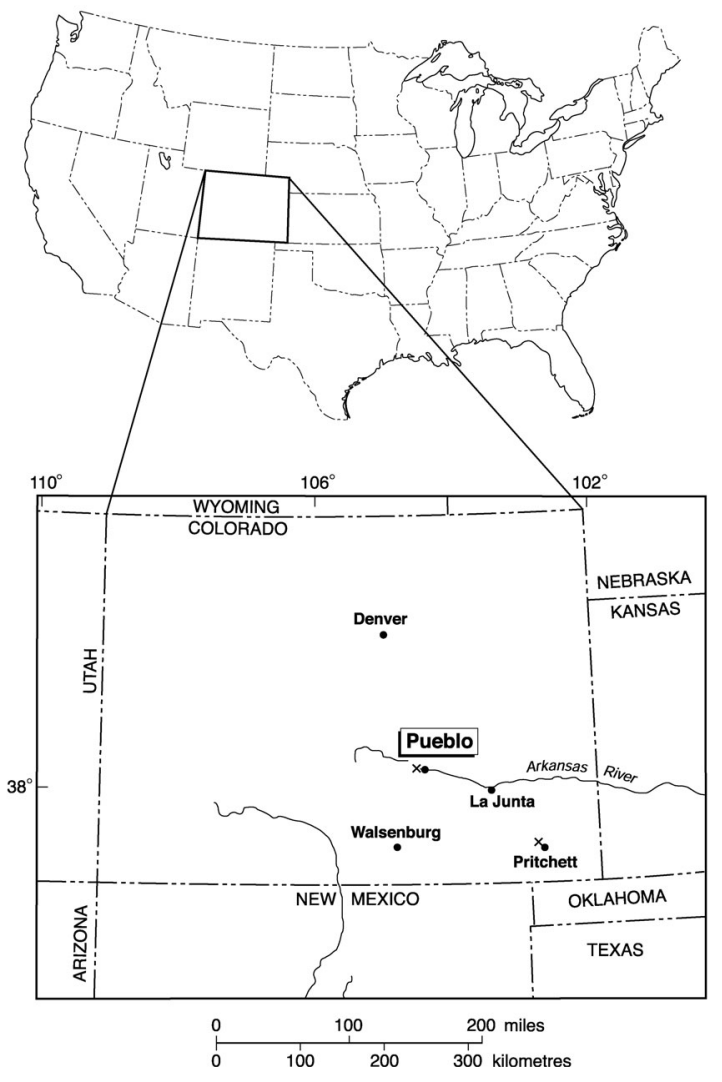

Figure 1 The location of Pueblo, Colorado, in the U.S. Western Interior.

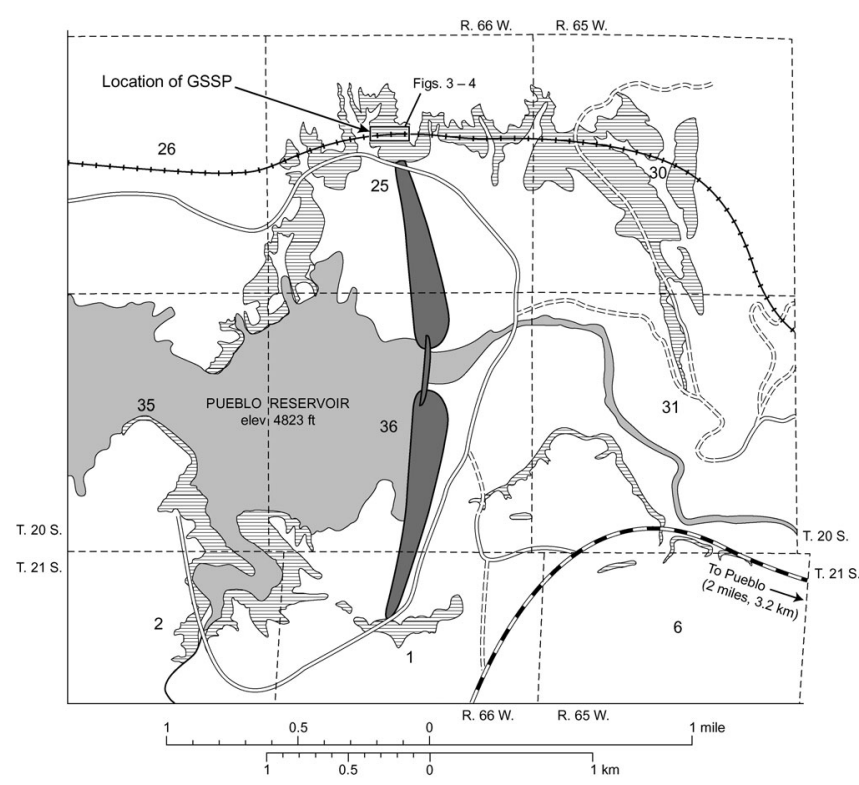

Figure 2 Geological sketch map of the area around the Pueblo Reservoir. The Global boundary Stratotype Section and Point for the base of the Turonian Stage is situated within the box marking the position of Figures 3-4 (based on Scott, 1964). Horizontal pattern shows outcrop of Greenhorn Limestone. 
(1985, 1987), Harries \& Kauffman (1990), Harries (1993) and Keller \& Pardo (2004) discuss extinctions across the interval, and there is much valuable and additional information in Pratt, Kauffman \& Zelt (1985).

The outcrop succession at Pueblo shows no obvious signs of condensation or non-sequence across the boundary interval and consists of diagenetically modified limestone-marl Milankovitch cycles, individual limestone and marl beds of which can be correlated across tens of thousands of square kilometres in the U.S. Western Interior (e.g. Hattin, 1971, 1975).

The section at the Rock Canyon anticline lies west of Pueblo, where the Arkansas River cuts through the Cretaceous section (Figures 1,2). As Kennedy \& Cobban (1991, p.10) note, the construction of a dam on the Arkansas River and subsequent development of a State Park (the Pueblo Reservoir Recreation Area) provide easy vehicular access, and although fossil collecting without permit is not possible from natural outcrops in the State Park (permission from bona fide workers will not normally be refused), relocation of the adjacent Denver and Rio Grande Western Railroad has exposed several kilometres of fresh cuts through the Bridge Creek Member of the Greenhorn Limestone.

\section{Location}

The GSSP (Figures 3-4) is located at the western end of the cuts on the Denver and Rio Grande Western Railroad, north of Pueblo Reservoir, west of Pueblo, Colorado, where the Arkansas River cuts through the Rock Canyon anticline (Figures 1,2). The area is semi-arid, with little vegetation cover, and there are semicontinuous exposures throughout most of the outcrop indicated in Figure 2. These outcrops form an arcuate belt several kilometers long mostly in secs. 25,35 , and 36 of T. 20S., R. 66W., and secs. 30 and 31, T. 20S., R. 65W., Northwest Pueblo $7 \frac{1}{2} 2$ minute quadrangle, scale 1:24,000, and lie within Townships 20 and 21 South, Ranges 65 and 66 west, latitude $38^{\circ}$ North, longitude $104^{\circ} 30^{\prime}$ 'West.

\section{Access}

Following the damming of the Arkansas River, the resultant reservoir has become the focus of the Pueblo State Recreation Area. Vehicular access is now possible by tarmac road, by taking State Highway 96 west from the center of Pueblo. Within the State Recreation Area, permission must be obtained prior to sampling by contacting the Rangers at the Park headquarters. All reasonable requests will be granted. Roads within the State Recreation Area are all tarmac. Figures 3, 4 show the GSSP, and there are further outcrops extending along the several kilometers of cut of the railroad immediately north of the State Recreation Area.

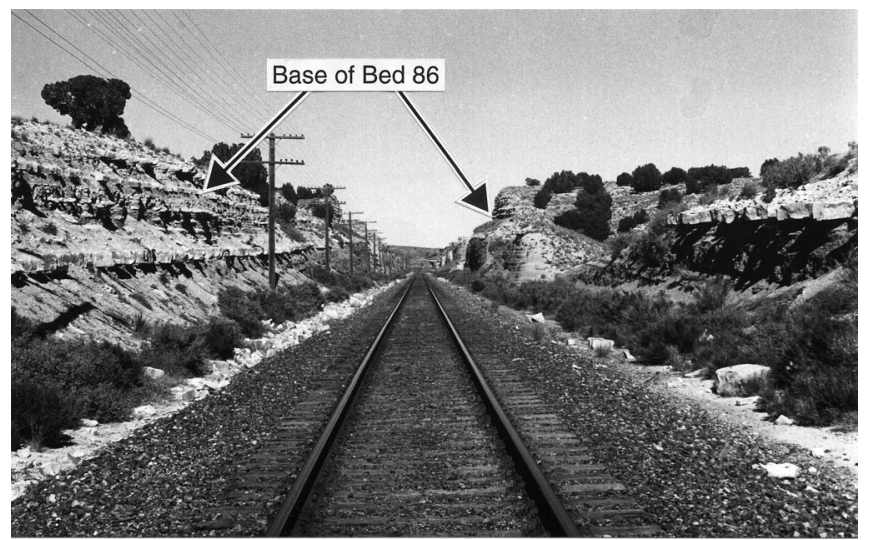

Figure 3 The GSSP for the base of the Turonian Stage. Cut at the western end of the Denver and Rio Grande Western Railroad at the north boundary of the Pueblo Reservoir State Recreation Area; see Figure 2 for location. The base of the Turonian Stage is drawn at the base of Bed 86 of the Bridge Creek Member of the Greenhorn Limestone.

\section{Description of the GSSP}

Table 1 is a detailed lithological log of the interval that encompasses the base of the Turonian Stage, which is within the Bridge Creek Member of the Greenhorn Limestone (Figure 5). Table 2 puts this unit in its regional lithostratigraphic context.

Figure 5 provides a summary lithostratigraphic section, with the base of the Turonian Stage indicated, as well as key bed-by-bed ammonite records.

Figure 8 gives data on the distribution of the inoceramid bivalves, key secondary markers in the boundary interval, following the taxonomic revision by Walaszczyk \& Cobban in Kennedy et al. (2000).

As can be seen from Figures 3, 4, the basic succession within the Bridge Creek Member is of alternations of limestone and shale; the alternations are in part primary in origin, accentuated by diagenetic redistribution of carbonate. Much of the sequence is bioturbated, with laminated and sublaminated units. Petrographically, the limestones are fossiliferous biomicrites.

The alternations in the Bridge Creek are climatically driven (Milankovitch) cycles, and individual beds are of wide geographical extent. Hattin (1971) was the first to demonstrate their wide distribution, and this work was extended by Elder $(1985,1987)$, Elder \& Kirkland (1985), and others. Individual marker beds can be traced for hundreds of kilometers away from Pueblo, into Kansas, New Mexico, Utah, and Arizona. The Bridge Creek Member is also characterized by the presence of bentonites, and several of these have been traced for equally long distances (Elder, 1988). Detailed descriptions of the lithostratigraphy of the Pueblo sequence are to be found in Scott (1964), Cobban \& Scott (1973), and in the many papers edited by Pratt, Kauffman \& Zelt (1985).

\section{The boundary level: primary and secondary biostratigraphic markers}

The boundary level is taken at the base of bed 86 of the section (Figure 5). This bed is indicated in Figures 3, 4. It is most easily recognized in the field by working up from the lowest, and very prominent limestone of the Bridge Creek Member: Bed 63, and there is a prominent yellow-weathering bentonite (bed 88 ) $50.4 \mathrm{~cm}$ above the top of bed 86 . The base of bed 86 corresponds to the first occurrence of the ammonite Watinoceras devonense (Wright \& Kennedy, 1981) in the section; the characteristic ammonite fauna of bed 86 is shown in Figure 6.

Apart from its occurrence at Pueblo, Watinoceras devonense also occurs elsewhere in bed 86 in Colorado, and in Southern England. There are also a series of secondary biostratigraphic markers for the basal boundary level in the Pueblo section; these are indicated in Figure 9. The ammonite, inoceramid bivalve, and dinoflagellate

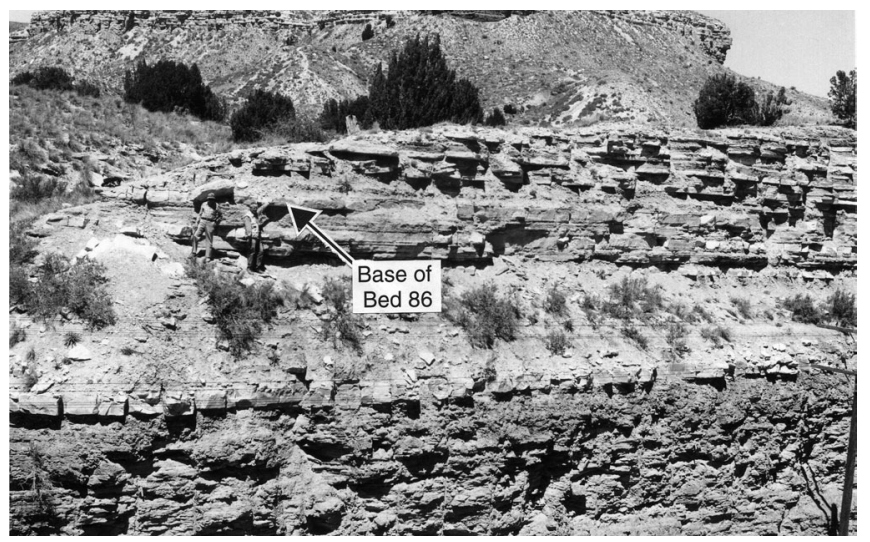

Figure 4 The GSSP for the base of the Turonian Stage. Cut on the north side of the Denver and Rio Grande Western Railroad (detail of Figure 3). The base of the Turonian Stage is drawn at the base of bed 86 of the Bridge Creek Member of the Greenhorn Limestone. 
Table 1 Principal reference section of Bridge Creek Member of the Greenhorn Limestone measured on Rock Canyon anticline in the NW1/4NE1/4 sec. 31, T. 20 S., R. 65 W., and in the SW1/4 and NW1/4NW1/4 sec. 30. T. 20 S., R. 65 W. Pueblo County, Colorado: from Cobban and Scott, 1973 with inoceramid names updated.

\section{Bridge Creek Member of the Greenhorn Limestone}

Calcarenite, shaly to platy; contains some fragments of Mytiloides and Collignoniceras woollgari -- -- -- -- -- -- -- -- --

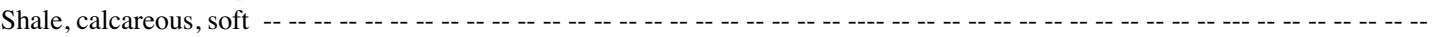

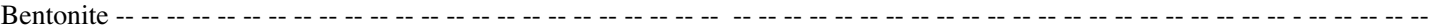

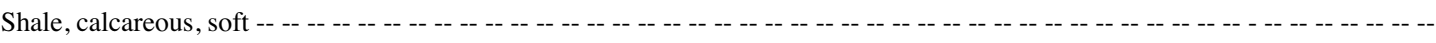
Shale, calcareous; contains numerous hard thin partings of calcarenite. Contains some fragments of Mytiloides - -- -- -- -- - - 1 Shale, calcareous, soft; contains a few thin partings of calcarenite -

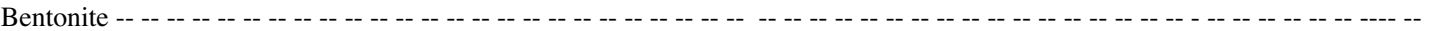

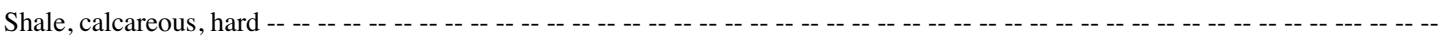

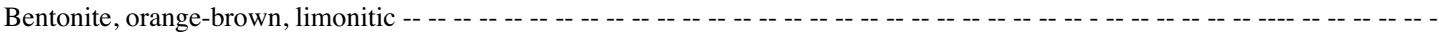

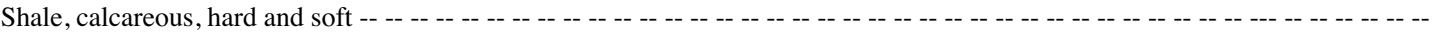

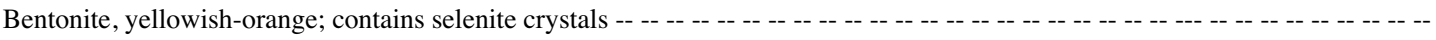

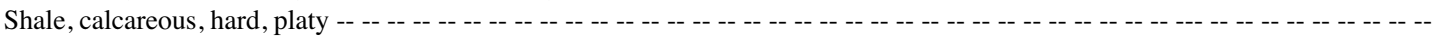

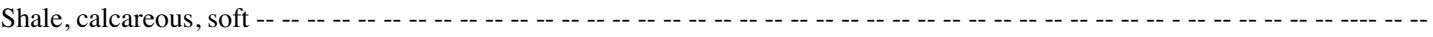
Limestone, shaly; contains fragments of $O$ strea and Mytiloides -- -- -- --

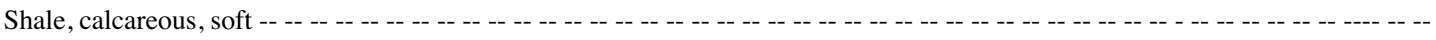

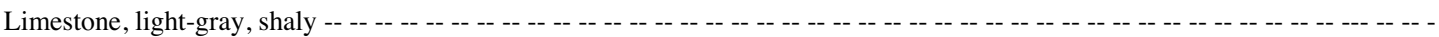
USGS D3985 and D3986: Mytiloides subhercynicus (Seitz), Collignoniceras woollgari (Mantell)

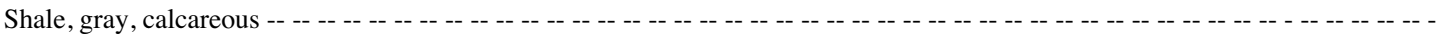

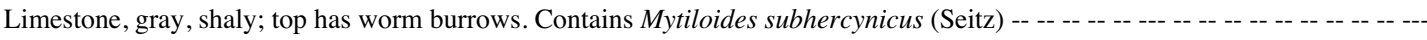

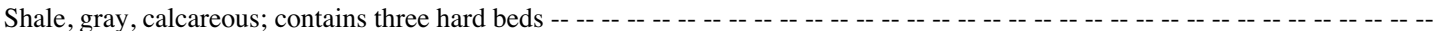
Shale; medium gray where fresh, orange brown where weathered, soft, calcareous; contains very thin partings of harder shale and calcarenite USGS D3983 at top: Baculites cf. B. yokoyamai Tokunaga and Shimizu, Collignoniceras woollgari (Mantell)

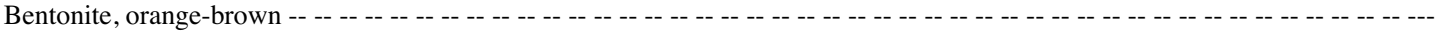

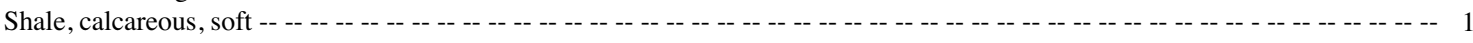

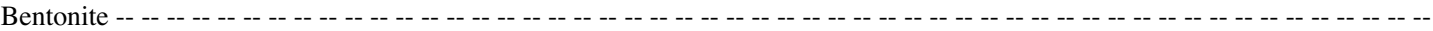

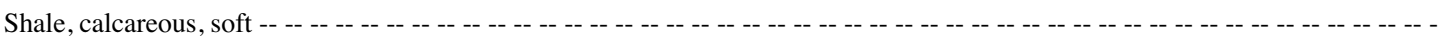
Shale, calcareous; contains thin hard partings of calcarenite and hard shale -- -- -- -- - - - - - - - - - 2

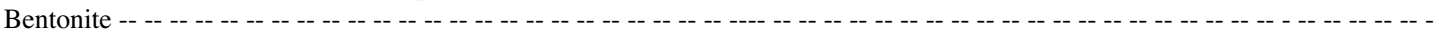

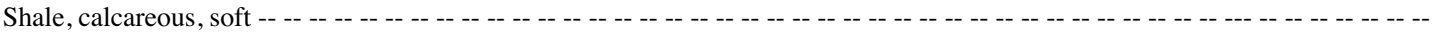
Calcarenite, shaly; contains fragments of Inoceramus

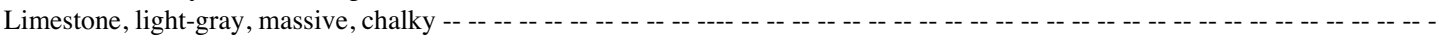

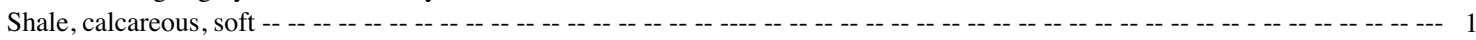
Limestone, gray, hard, irregularly bedded. Forms top of bluff locally USGS D3982: Mytiloides mytiloides (Mantell), Morrowites wingi (Morrow)

Shale, gray, calcareous -- -- -- -- -- -- -- -- -- -- -- -- --

Limestone, gray, hard, irregularly bedded. Commonly forms top of bluff -USGS D3981: Mytiloides mytiloides (Mantell), Baculites cf. B. yokoyamai Tokunaga and Shimizu, Morrowites wingi (Morrow) Shale, gray, calcareous -- -- -- -- -- -- -- -- -- -- -- -- -- -- -- -- -- -- -- -- -- -- -- -- -- -- -- -- -- -- -- -- -- -- -- -- -- - -- -- -- -- -- -- --- -Limestone, gray, hard, irregularly bedded. Contains Mytiloides mytiloides (Mantell) -- -- -- -- -- -- -- -- -- -- -- --

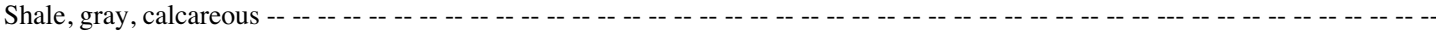

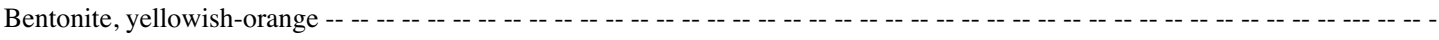
USGS D3980: Mytiloides mytiloides (Mantell), M. ganuzai Lopez, M. goppelnensis (Badillet and Sornay), Baculites cf. B. yokoyamai Tokunaga and Shimizu

Shale, gray, calcareous -- - - - - - - -

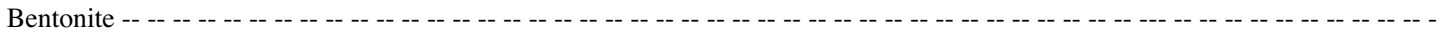

Shale, gray, calcareous -- -- -- -- -- -- -- -- -- -- -- -- -- -- -- -- -- -- --- -- -- -- -- -- -- -- -- -- -- - -- -- -- -- -- -- ---- -- -- -- -- -- -- -- --

Limestone, gray, shaly. Contains Mytiloides sp.

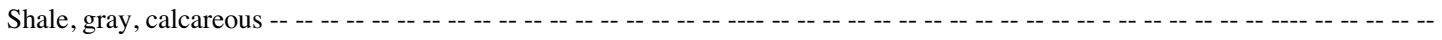
Limestone, gray, shaly. M. mytiloides (Mantell), M. goppelnensis (Badillet and Sornay), -- -- -- - - -- -- -- -- -- -- - -

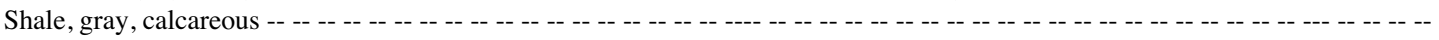
Limestone, gray, hard, massive to shaly. Fragments of Puebloites rather common -USGS D3979: Mytiloides kossmati (Heinz), M. labiatus (Schlotheim), Puebloites greenhornensis Cobban and Scott, Tragodesmoceras bassi Morrow sp., Kamerunoceras puebloense, Morrowites wingi (Morrow), Choffaticeras pavillieri (Pervin-

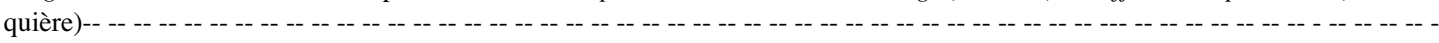

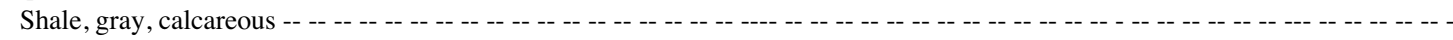

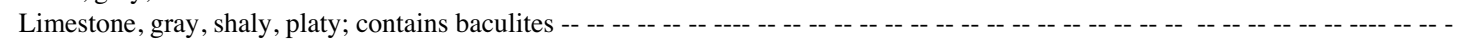
Shale, gray, calcareous; middle is harder and in part a shaly limestone that contains abundant pelagic Foraminifera and some flat-

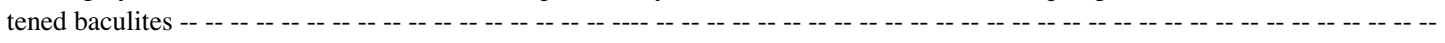
02 Limestone, gray, hard, somewhat shaly; contains pyrite in places tus (Schlotheim)

01 Shale, gray, calcareous - 


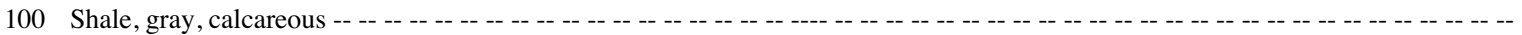

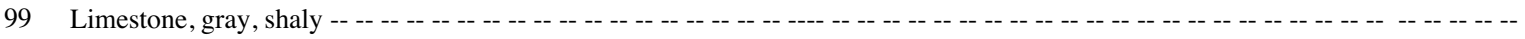

8 Shale, gray, calcareous $\quad$ Limestone, gray, hard, irregularly bedded; contains horizontal burrows and here and there grayish-green patches and films of

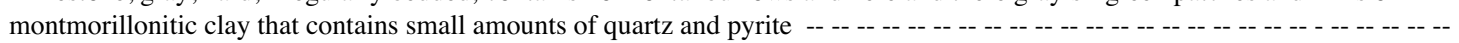
USGS D3977: Mytiloides kossmati (Heinz), M. puebloensis, M. goppelnensis, M. labiatus, Ostrea sp., Puebloites spiralis Cobban and Scott, Watinoceras coloradoense (Henderson), W. reesidei Warren?, Vascoceras (Greenhornoceras) birchbyi Cobban and Scott, Fagesia sp.

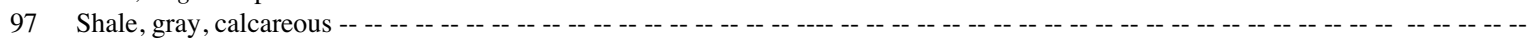

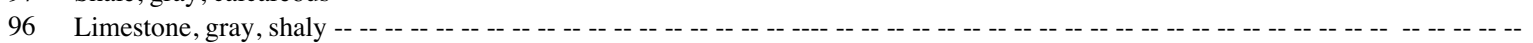

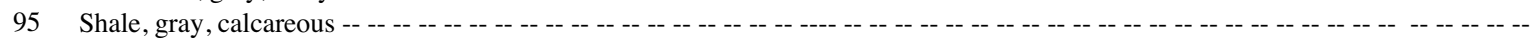

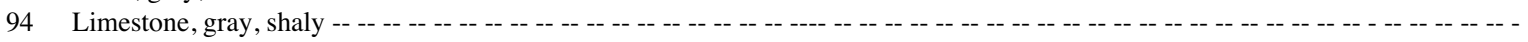

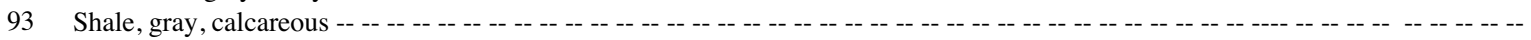

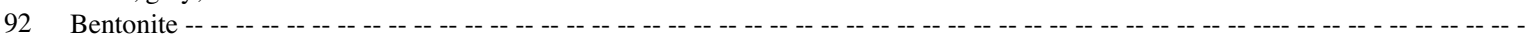

91 Limestone, gray, hard, massive; weathers yellowish gray; contains numerous horizontal burrows filled with limonitic marl that

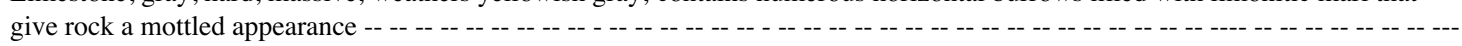
USGS D3976: Mytiloides puebloensis, M. kossmati, M. hattini, Ostrea sp., Baculites cf. B. yokoyamai Tokunaga and Shimizu, Puebloites sp.

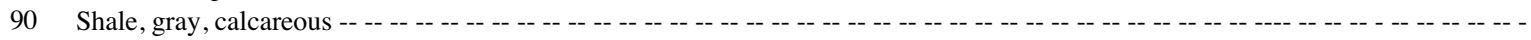

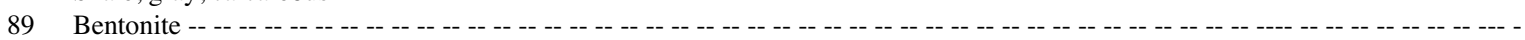

88 Shale, gray, calcareous -- -- -- -- -- -- -- -- -- -- -- -- -- -- -- -- -- -- -- -- -- -- -- -- -- -- -- -- -- -- -- -- -- -- -- -- ---- - -- -- -- -- -- -- --- --

87 Limestone, gray, hard; largely massive but upper few inches shaly; contains abundant pelagic Foraminifera and some mollusks -- USGS D3975: Mytiloides hattini Elder, M. puebloensis, Puebloites? sp., Kanabiceras sp., Anisoceras sp.

\section{BASE TURONIAN}

86

85

84

83

82

81

80

79
78

78

77

76

75

74

$$
\text { in; }
$$

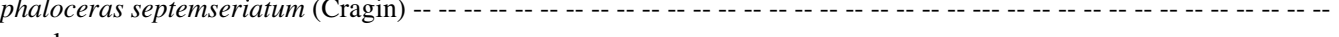

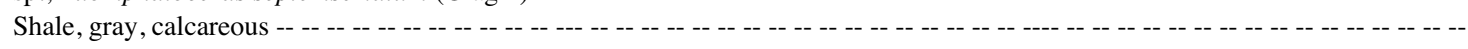

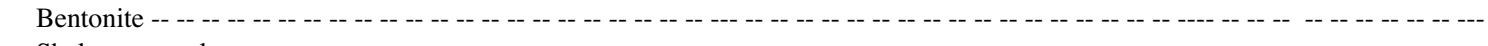

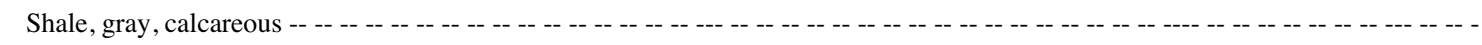

Bentonite, yellowish-orange, limonitic -- -- -- -- -- -- -- -- -- -- -- -- -- -- -- -- -- -- -- -- -- -- -- -- --

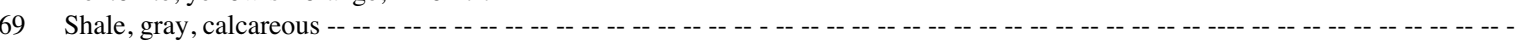

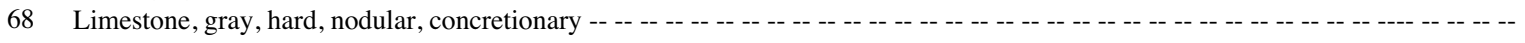

USGS D3973 and D6472: Holaster feralis Cooke, Camptonectes sp., Gastropods (sparse), Hemiptychoceras reesidei Cobban and

Scott, Sciponoceras gracile (Shumard), Allocrioceras annulatum (Shumard), Puebloites corrugatus (Stanton), Pseudocalycoceras angolaense (Spath), Euomphaloceras septemseriatum (Cragin), Metoicoceras geslinianum (d'Orbigny)

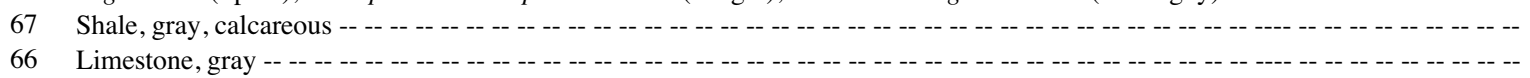

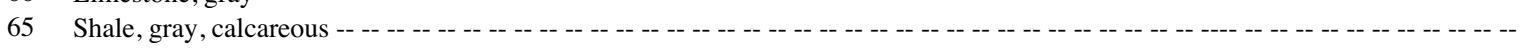

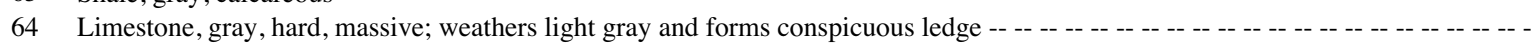

63 USGS D3972 and D6473: Inoceramus pictus Sowerby, Calycoceras cf. C. naviculare (Mantell), Metoicoceras sp.

Total Bridge Creek Member (rounded)

records fom the sequence are not in dispute. There are, in contrast, differences in the planktic foraminiferan record between the results of Eicher \& Diner (1985) and Leckie (1985), which we incorporated in the original submission and those in Keller \& Pardo (2004) and Keller et al. (2004), and records in Caron et al. ( in press). The latter also differ from those in Keller \& Pardo (2004) and Keller et al. (2004). We are unable to resolve these differences, and in consequence retain our original conclusions, pending resolution of disparities in the planktic foraminiferan record in subsequent publications.

On this basis, the sequence of secondary markers, from lowest to highest, is:
1. The last occurrence of Rotalipora greenhornensis (Morrow) and Rotalipora deekei in the top $25 \mathrm{~cm}$ of the Hartland Shale, below Bed 63 of the Bridge Creek Member.

2. The first occurrence of the ammonite Metoicoceras geslinianum (d'Orbigny) at the base of bed 63, and last occurrence in bed 67 (geographic range: Wyoming, Montana, Utah, Colorado, Kansas, Arizona, New Mexico, and Texas in the United States; Mexico, southern England, France, Spain, Germany, Czech Republic, Iran (?), Angola, Nigeria, and, possibly, Morocco).

3. The last occurrence of Rotalipora cushmani (Morrow) in the thin bentonite layer $15 \mathrm{~cm}$ above the top of Bed 63 . 
Table 2 The Graneros Shale to Carlile Shale west of Pueblo, Colorado (modified after Scott, 1964).

\begin{tabular}{|c|c|c|}
\hline Formation & Member & Thickness and lithology \\
\hline \multirow[b]{3}{*}{$\begin{array}{l}\text { Carlile } \\
\text { Shale }\end{array}$} & Juana Lopez & $0-0.6 \mathrm{~m}(2 \mathrm{ft})$ fetid calcarenite (dark shale) \\
\hline & Codell Sst & $9.15 \mathrm{~m}$ (30ft) cliff forming sandstone \\
\hline & $\begin{array}{l}\text { Blue Hill } \\
\text { Shell }\end{array}$ & $\begin{array}{l}30.8 \mathrm{~m}(101 \mathrm{ft}) \text { dark grey, hard to soft } \\
\text { blocky shale; sandy in upper half, with two } \\
\text { layers of large septarian concretions }\end{array}$ \\
\hline \multirow{4}{*}{$\begin{array}{l}\text { Greenhorn } \\
\text { Limestone }\end{array}$} & $\begin{array}{c}\text { Fairport } \\
\text { Chalky Shale }\end{array}$ & $\begin{array}{l}30.2 \mathrm{~m}(99 \mathrm{ft}) \text { grey to yellowish-brown soft } \\
\text { bentonitic platy calcareous shale }\end{array}$ \\
\hline & $\begin{array}{l}\text { Bridecreek } \\
\text { Limestone }\end{array}$ & $\begin{array}{l}15.8 \mathrm{~m}(52 \mathrm{ft}) \text { hard, grey, shaley weathering } \\
\text { limestones, interbedded with soft calcareous } \\
\text { shale and bentonite }\end{array}$ \\
\hline & $\begin{array}{l}\text { Hartland } \\
\text { Shale }\end{array}$ & $\begin{array}{l}18 \mathrm{~m}(59 \mathrm{ft}) \text { dark grey calcacreous shales } \\
\text { with thin layers of calcarenite and bentonite }\end{array}$ \\
\hline & $\begin{array}{l}\text { Lincoln } \\
\text { Limestone }\end{array}$ & $\begin{array}{l}11.6 \mathrm{~m}(38 \mathrm{ft}) \text { grey limestone-shale } \\
\text { alternations with bentonites }\end{array}$ \\
\hline $\begin{array}{l}\text { Graneros } \\
\text { Shale }\end{array}$ & & $\begin{array}{l}31.4 \mathrm{~m}(103 \mathrm{ft}) \text { dark-grey fissile soft to } \\
\text { medium-hard non-calcareous shale with } \\
\text { numerous bentonites }\end{array}$ \\
\hline
\end{tabular}

4. The first occurrence of the ammonite Euomphaloceras septemseriatum (Cragin) is bed 67 and last occurrence in bed 77 (geographic range; Wyoming, Montana, Utah, Colorado, Kansas, Oklahoma, Arizona, New Mexico, and Texas in the United States; Mexico, southern England, France, Germany, Nigeria, Angola, Japan).

5. The last occurrence of Globigerinella bentonensis (Morrow) near the base of Bed 68, $66 \mathrm{~cm}$ above the top of limestone Bed 63 , and $40 \mathrm{~cm}$ above the last occurrence of $R$. cushmani.

6. The Heterohelix shift in Bed 78, which marks dominance $(\sim 80 \%)$ of this low oxygen tolerant taxon and signals anoxic conditions. To date the Heterohelix shift has also been recognized in southern England, France and Tunisia.

7. The first occurrence of the ammonite Neocardioceras juddii (Barrois \& Guerne) in bed 79, and its last occurrence in bed 84 (geographic range: Montana, Colorado, Utah, New Mexico, Arizona, southern England, France, Germany, Czech Republic).

8. The last occurrence of the bivalve Inoceramus pictus J. de C. Sowerby in bed 84 (geographic range: Wyoming, Montana, Utah, Colorado, Kansas, Oklahoma, Arizona, New Mexico, and Texas in the United States, England, France, Germany, Poland, Czech Republic, Russia, Kazakhstan, Madagascar).

9. The first occurrence of the bivalve Mytiloides hattini Elder (Figure 7. 6-8, 10-15) in the topmost part of bed 84 , and last occurrence in the lower part of Bed 99 (geographic range: Colorado, Kansas, Utah, and Arizona in the United States; Southern England, France, Spain, Portugal, Germany, Kazakstan, Russia).

10.The last occurrence of the nannofossil Microstaurus chiastius between beds 85 and 88 .

11. The primary marker: the first occurrence of the ammonite Watinoceras devonense Wright \& Kennedy, 1981, in bed 86.

12. The first occurrence of the bivalve Mytiloides puebloensis Walaszczyk and Cobban in bed 86, and last occurrence in bed 105 (geographic distribution Colorado, Kansas, New Mexico in the United States; Portugal).
13. The first occurrence of the planktic foraminifer Helvetoglobotruncana helvetica (Bolli) in bed 89. ( $H$. praehelveticahelvetica transitional forms occur in beds 85 and 87 ).

14. The first occurrence of the bivalve Mytiloides kossmati (Heinz) in bed 90, and last occurrence in bed 105 (geographic distribution: Colorado, Utah, in the United States, Germany, Russia, Kazakhstan, Madagascar and Japan).

15. The first occurrence of the ammonite Mammites nodosoides (Schlüter) in bed 101, and its last occurrence in bed 118 (geographic distribution: Montana, Wyoming, Utah, Colorado, South Dakota, Arizona, Kansas, New Mexico, Texas, in the United States; Mexico, England, France, Spain, Germany, the Czech Republic, Romania, Kazakhstan, Iran (?), Lebanon, Israel, Algeria, Tunisia, Morocco(?), Angola, Nigeria, Madagascar, Colombia, Venezuela, Peru, Brazil).

16. The first occurrence of the bivalve Mytiloides mytiloides (Mantell) in bed 105 (geographic distribution: Montana, Wyoming, South Dakota, Kansas, Oklahoma, Colorado, Utah, Arizona, and New Mexico in the United States; Europe, Western Asia, Madagascar, Japan).

17.Dodsworth (2000) has recently documented the dinoflagellate cyst biostratigraphy across the Cenomanian-Turonian boundary in the Pueblo section, and noted the disappearance of consistent/common Litosphaeridium siphoniphorum (Cookson and Eisenack) Davey and Williams in bed 73 .

18. The first occurrence of Heterosphaeridium difficile (Manum and Cookson) loannides in bed 95 . These events have been correlated inter-regionally.

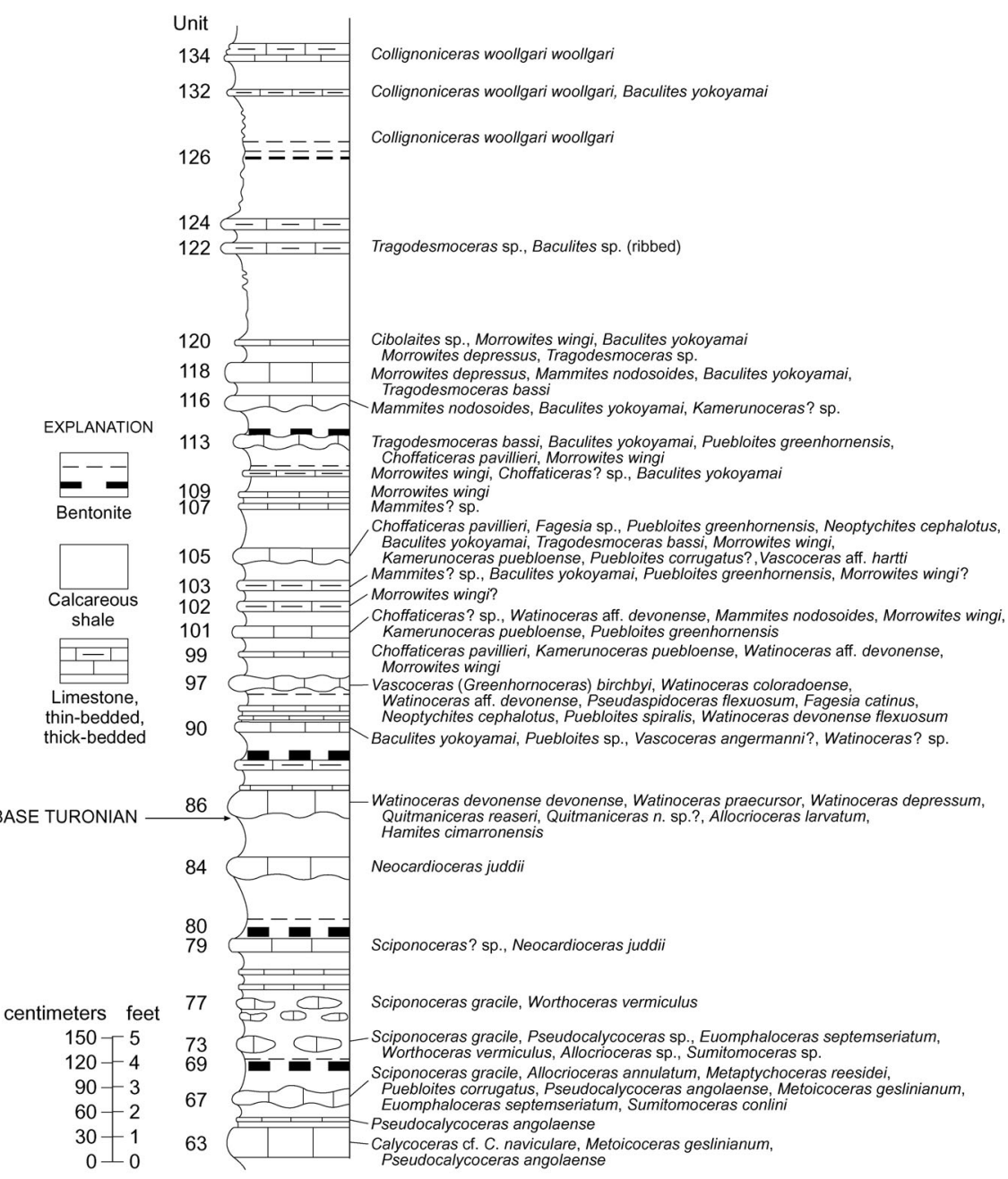

Figure 5 Lithological succession in the Bridge Creek Member of the Greenhorn Limestone on the north side of Pueblo Reservoir State Recreation Area, in sec. 25, T. $20 S ., R .66 \mathrm{~W}$., with principal ammonite occurrences marked. The base of the Turonian Stage is drawn at the base of bed 86 (modified after Cobban \& Kennedy, 1991). 


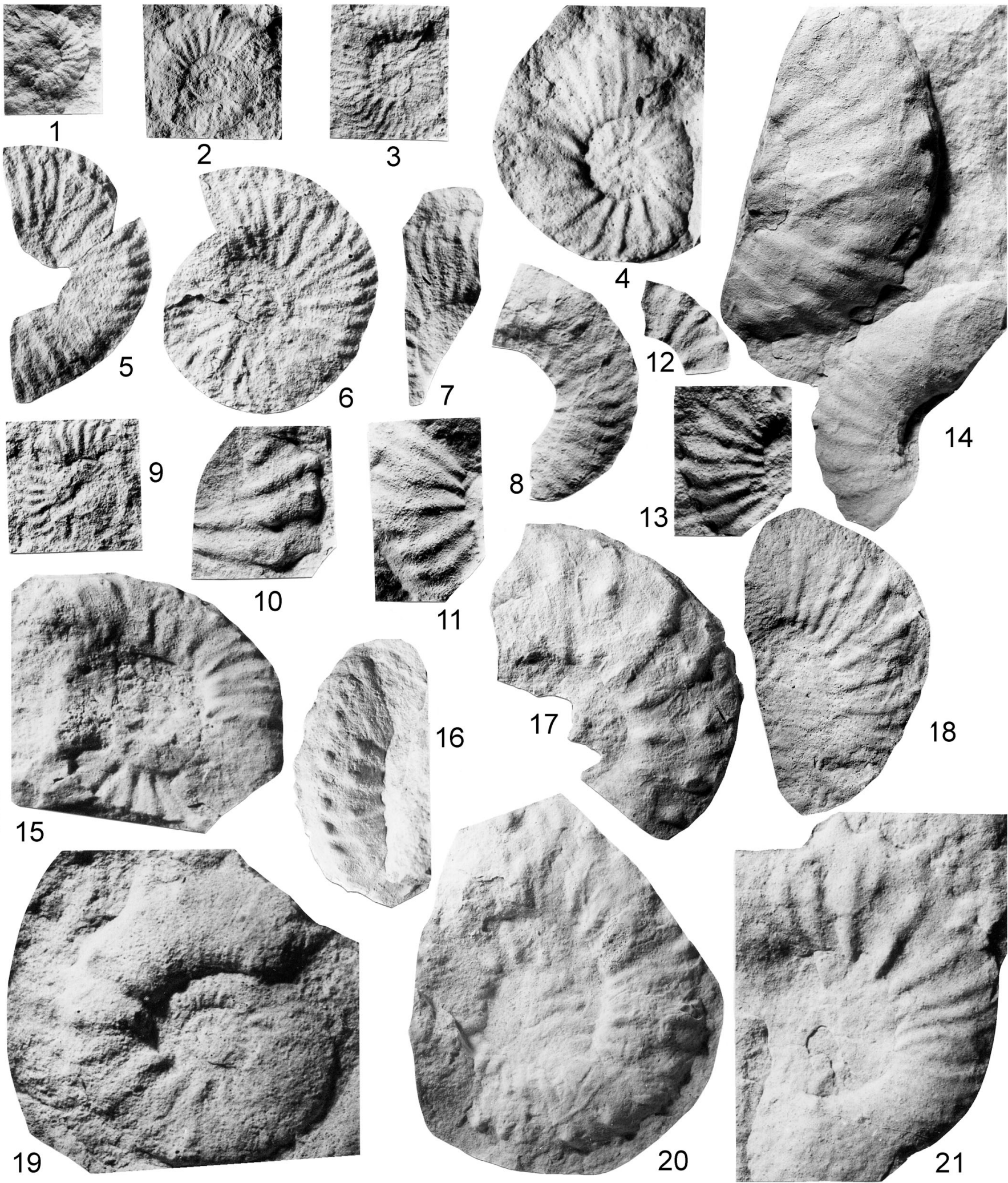

Figure 6 Ammonites from the Watinoceras devonense Zone fauna of bed 86 of the Bridge Creek Member of the Greenhorn Limestone. 1-4, 14-18, 20, 21. Watinoceras praecursor Wright \& Kennedy, 1981. 1, USNM 441443, from locality D12715. 2, USNM 441441, from locality D12715. A latex cast. 3, USNM 441440, from locality D12715. A latex cast. 4, USNM 460750, from locality D12715. A latex cast. 14, USNM 460735, from locality D13246. 15, 16, USNM 460736, from locality D13246. 17, USNM 441438, from locality D6123. 18, USNM 442106, from locality D3975. A latex cast. 20, USNM 441442, from locality D12460. A latex cast. 21, USNM 460737, from locality D13246. 5-7, 12, Watinoceras devonense devonense Wright \& Kennedy, 1981. 5, 6, USNM 441445, from locality D3975. Figure 5 is latex cast. 7, USNM 441447, from locality D3975. 12, USNM 441446, from locality D10176. 9-11, 13, 19, Watinoceras depressum Wright \& Kennedy, 1981. 9, USNM 441450, from locality D12715. 10, USNM 441452, from locality D12715. 11, USNM 441451, from locality D12715. 13, USNM 441448, from locality D12715. 19, USNM 460749, from locality D12715. 8, Quitmaniceras reaseri Powell, 1963, USNM 441468, from locality D12715. All figures are original size. 


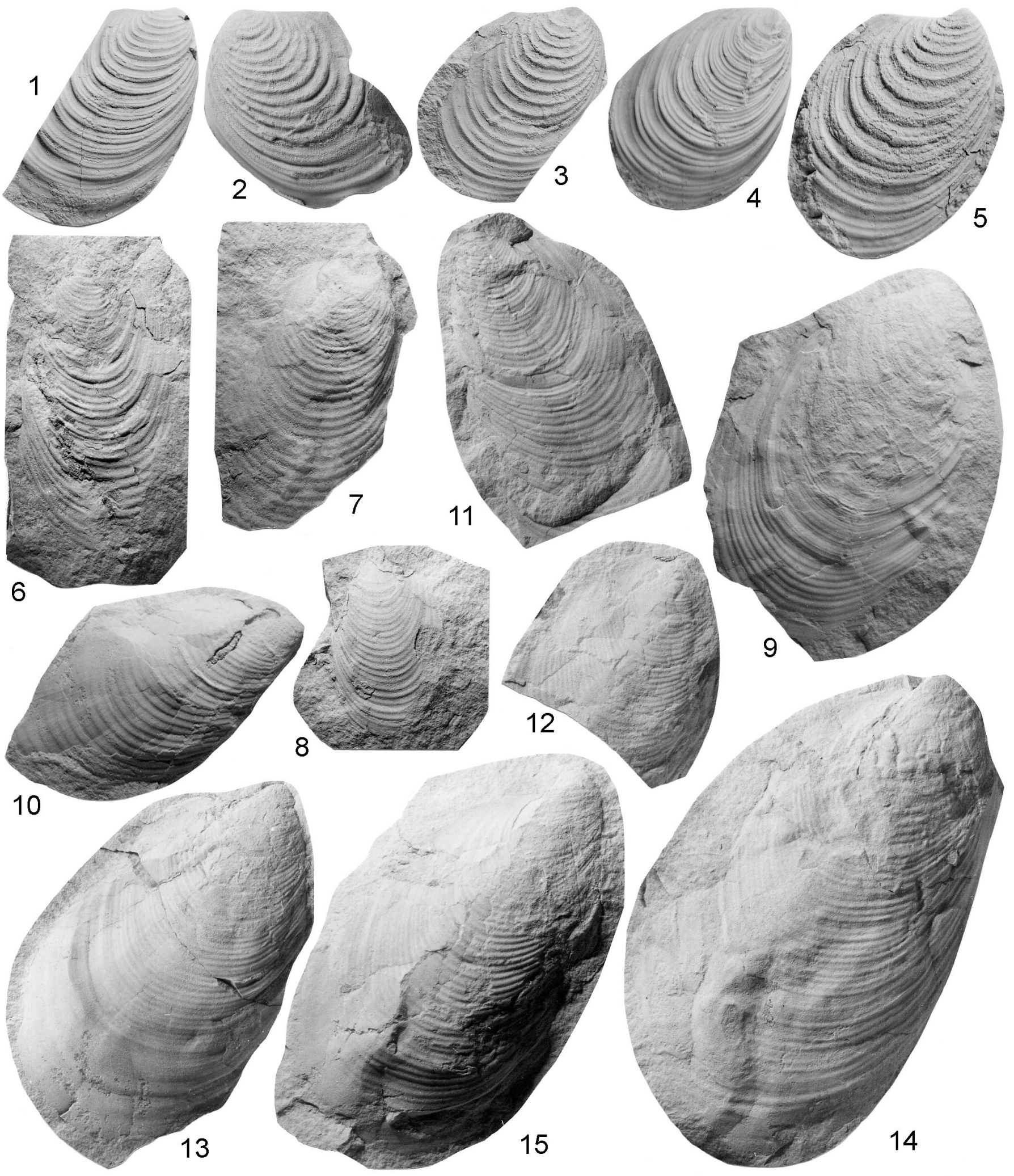

Figure 7 Mytiloides species that are key secondary markers for the base of the Turonian Stage in the Pueblo section.

1, 4-5, Lower Turonian Mytiloides puebloensis Walaszczyk and Cobban. 2-3, M. goppelnensis (Badillet and Sornay) from bed 97 of the Bridge Creek Member of the Greenhorn Limestone at USGS Mesozoic locality D6147, $\mathrm{NW}^{1 / 4}, \mathrm{NW}^{1 / 4}$, sec. 1, and NE $\mathrm{N}_{4} \mathrm{NE}^{1 / 4} \mathrm{sec} .2, \mathrm{~T} .21 \mathrm{~S}$., R. 66W., Pueblo, Colorado. 1, USNM 441477; 2, USNM 441480; 3, USNM 441479; 4, USNM 441476; 5, USNM 441478. 6-8, 10-15, Lower Turonian Mytiloides hattini Elder. 9, M. puebloensis Walaszczyk and Cobban, from bed 86 of the Bridge Creek Member of the Greenhorn Limestone. 6, USNM 441470; 7, USNM 441469; 8, USNM 441471, all from USGS Mesozoic locality D3975, SW1/4, sec, 30, T. 20S., R. 65W., Pueblo County, Colorado. 9, USNM 507293; 13, USNM 507298; 15, USNM 507299, all from USGS Mesozoic locality D12460; 10, USNM 507294; 11, USNM 507295; 12, USNM 507296; 14, USNM 507752; from USGS Mesozoic locality D10176, in the center of sec. 25, T.20S., R. 66W., Pueblo County, Colorado. All figures are original size. 


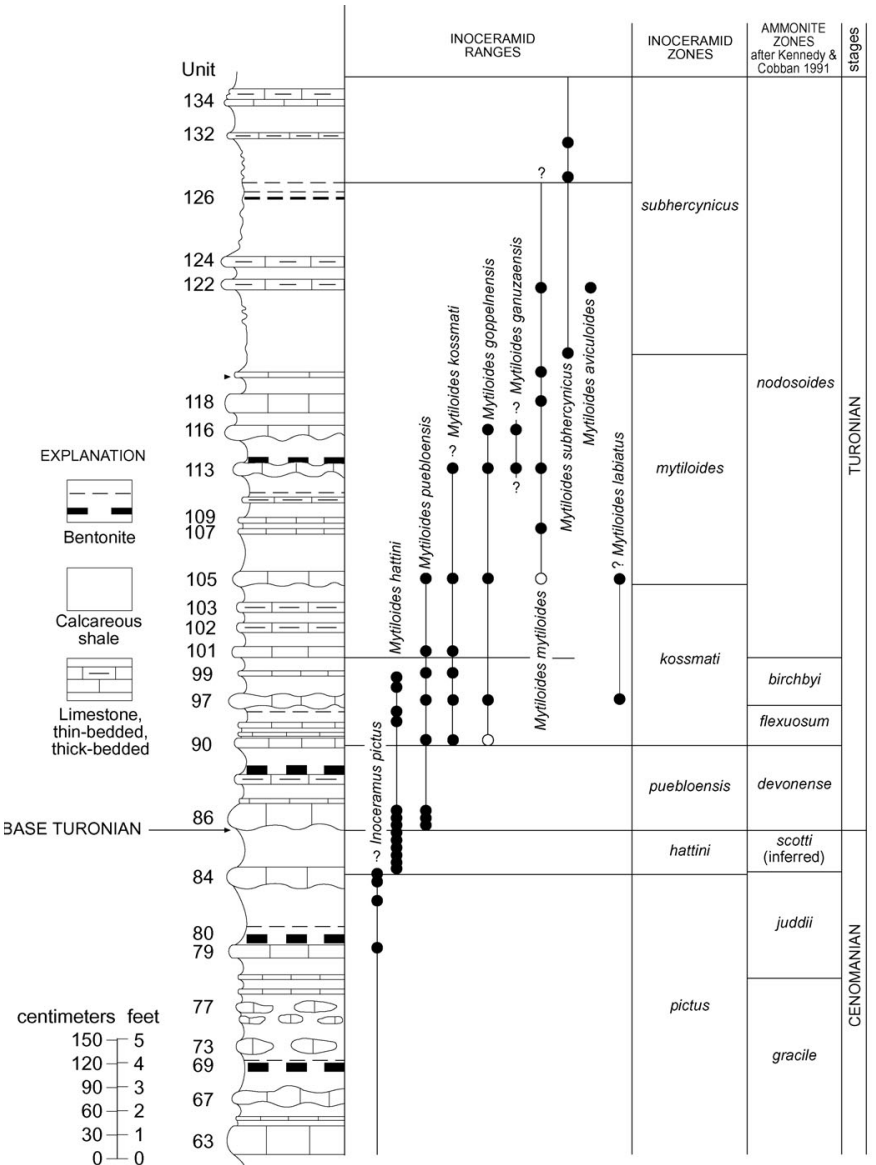

Figure 8 Lithological succession in the Bridge Creek Member of the Greenhorn Limestone on the north side of the Pueblo Reservoir State Recreation area, in sec. $25, T$. 20S., R. 65W., with ranges of key inoceramid bivalves and zonation by Walaszczyk \& Cobban in Kennedy et. al (2000); ammonite zones after Kennedy \& Cobban (1991).

\section{Stable isotope stratigraphy of the boundary interval}

It is now well-established that the Cenomanian-Turonian boundary interval was characterized by abnormally high rates of burial of organic carbon in the marine realm, leading to a positive (heavy) carbon isotope excursion in the marine carbonate record that defines what has become known as an Oceanic Anoxic Event (OAEII) (Schlanger \& Jenkyns, 1976; Jenkyns, 1980; Schlanger et al., 1987; Scholle \& Arthur, 1980, Tsikos et al., 2004).

This anoxic event and corresponding positive (heavy) excursion in carbon stable isotope excursion was first demonstrated in the Pueblo sequence by analysis of a core drilled within the Pueblo Recreation area in the NW1/4 NW1/4 NE1/4 Sec. 31, T. 20S., R. 65W. (Figure 2), and comprehensively documented by Pratt (1981, 1983, 1984, 1985) and discussed by Pratt, Kauffman \& Elder (1983), Pratt \& Threlkeld (1984), Elder $(1985,1987)$, Arthur, Dean and Pratt (1988), Gale et al. (1993), Accarie et al. (1996) and others. High resolution carbon isotope analysis was recently conducted on the planktic foraminifer Hedbergella planispira (Keller et al., 2004) .

$\delta^{13}$ Corg (PDB) data published in Gale et al. (2005) are plotted against the $\log$ of the Cenomanian-Turonian boundary interval in Figure 10. It will be seen that the base of bed 86 falls immediately below the third positive peak in the curve.

It is now known that expanded Cenomanian-Turonian boundary sections in pelagic facies in other parts of the Western Interior (e.g. Pratt, 1985; Pratt, Arthur, Dean \& Scholle, 1993), in southern England (Gale et al., 1993: Paul et al., 1999; Keller et al., 2001;

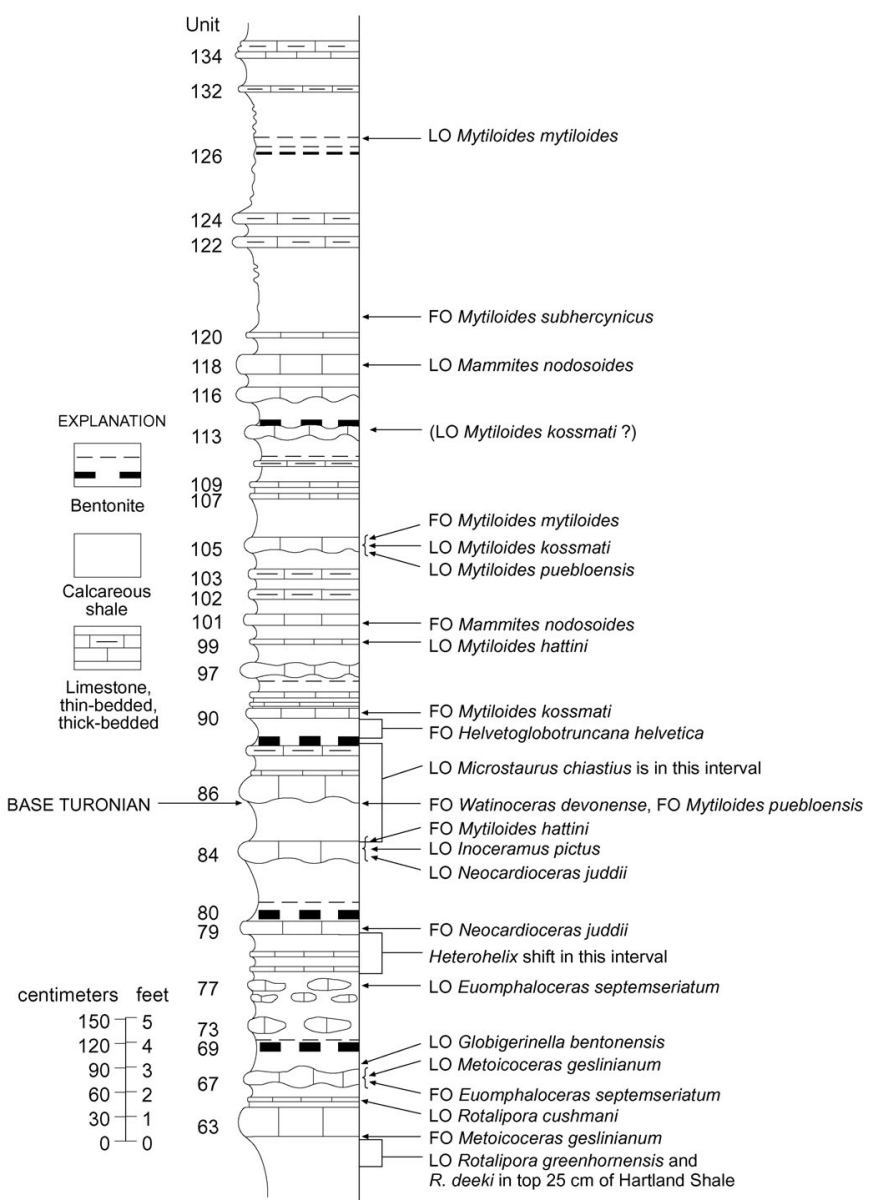

Figure 9 The primary and secondary markers for the base of the Turonian Stage, plotted on the outcrop section of the GSSP in the cut at the western end of the Denver and Rio Grande Western Railway north of the Pueblo State Reservoir Recreation Area. $L O=$ last occurrence $; \mathrm{FO}=$ first occurrence .

Tsikos et al., 2004), northern Spain (Paul et al., 1994), northern Tunisia (Accarie et al., 1996) and Japan (Hagesawa, 1995) preserve similarly ornate excursion, and that peaks and troughs in the curve can be correlated between sections (Gale et al., 1993). This is demonstrated in Figure 10, which compares the curve from Pueblo with that from Eastbourne, Sussex, England (after Gale et al., 2005).

\section{Radioisotopic dating of the boundary interval}

No less than four prominent bentonites occur in the boundary interval, as well as a number of minor bentonitic levels. Integration of biostratigraphy, lithostratigraphy and chemostratigraphy show these bentonites to be widely recognisable throughout the U.S. Western Interior. We have failed to obtain satisfactory dates from the Pueblo section where the bentonites are thin and weathered, but correlative bentonites in Arizona and Nebraska have provided ${ }^{40} \mathrm{Ar} /{ }^{39} \mathrm{Ar}$ ages that can be tied to the coeval bentonites in the Pueblo section; identifying numbers in parentheses correspond to those in Obradovich (1993). From oldest to youngest:

(22) Marker bed BM5, $0.9 \mathrm{~m}$ bentonite, $5.7 \mathrm{~m}$ above base of Mancos Shale (lower calcareous shale member), Lohali Point, Black Mesa, NE Arizona (Kirkland, 1991, 1996), corresponding to bed 64 at Pueblo. $93.90 \pm 0.72 \mathrm{Ma}$.

(21) Marker bed BM6, $22.5 \mathrm{~cm}$ bentonite $6.8 \mathrm{~m}$ above base of Mancos Shale (lower calcareous shale member), Lohali Point, Black Mesa, NE Arizona (Kirkland, 1991, 1996), corresponding to bed 69 at Pueblo. $93.49 \pm 0.89 \mathrm{Ma}$. 
(20) Bentonite in upper third of Neocardioceras juddii Zone in sec. 33, T.31N., R. 20W., Rocky Point Quadrangle, San Juan County, New Mexico, correlated with bed 80 at Pueblo. $93.78 \pm 0.49 \mathrm{Ma}$; $93.59 \pm 0.58 \mathrm{Ma}$

(20) Bentonite in Greenhorn Limestone Member, corresponding to HL3 marker bed of Hattin (1975) and Bed 80 at Pueblo; Alexandria Quadrangle, Little Blue River, in NE1/4 Sec. 5, T. 2N., R.1N, Thayer County, Nebraska. $93.30 \pm 0.4 \mathrm{Ma}$

(19) Marker bed BM15, $0.6 \mathrm{~m}$ bentonite, $6.4 \mathrm{~m}$ above base of Mancos Shale (lower calcareous shale member), Lohali Point, Black Mesa, NE Arizona (Kirkland, 1991, 1996), corresponding to bed 88 at Pueblo. $93.25 \pm 0.5 \mathrm{Ma}$.

(18) Marker bed BM17, $0.16 \mathrm{~m}$ bentonite, $25 \mathrm{~m}$ above base of Mancos Shale (lower calcareous shale member), Lohali Point, Black Mesa, NE Arizona (Kirkland, 1991, 1996), corresponding to bed 96 at Pueblo. $93.40 \pm 0.63 \mathrm{Ma}$.

These radiometric dates are plotted onto Figure 10

On the basis of these data, Obradovich (1993) dated the Cenomanian-Turonian boundary at $93.3 \pm 0.2 \mathrm{Ma}$; note that dates around the boundary level are not without problems, as discussed by Obradovich. Kowallis et al. (1995) dated the boundary at $93.1 \pm 0.3 \mathrm{Ma}$.

\section{Conclusions}

The proposed Global Boundary Stratotype Section and Point for the base of the Turonian Stage near Pueblo, Colorado fulfils the following requirements set out by Remane et al. (1996):
- Exposures extend over an adequate thickness, and the boundary is well defined by both primary and secondary (auxiliary) biostratigraphic markers.

- The Pueblo section can be traced laterally over several kilometers distance.

- The pelagic, climatically driven, rhythmically bedded Milankovitch sequence shows no evidence for gaps or for condensation in the proximity of the proposed boundary. (Meyers, Sageman \& Hinnov, 2001) analysed the sequence in the No. 1 Portland core numerically, and concluded that there is a hiatus in the lower part of bed 78, of an estimated 25,000 years duration. These authors noted that this proposed hiatus is not readily apparent in the core, or at outcrop in the Pueblo area. The proposed hiatus lies in the lower part of a shale unit, within the Neocardioceras juddi Zone, and well below the GSSP at the base of bed 86 . It does not compromise the GSSP. Meyers et. al found no other evidence for hiatus within the sequence.

- The rate of sedimentation is sufficiently high that the successive biostratigraphic and isotopic events used as secondary markers are clearly separated.

- There is no synsedimentary or tectonic disturbance in the boundary interval.

- Neither metamorphic nor strong diagenetic alteration of the boundary sequence has occurred.

- There is a well-preserved abundant and diverse fossil record across the boundary interval, with key markers for uppermost Cenomanian and Lower Turonian intercontinental biostratigraphic correlation: ammonites, inoceramid bivalves, planktic forams, dinoflagellates, and nannofossils well-represented.

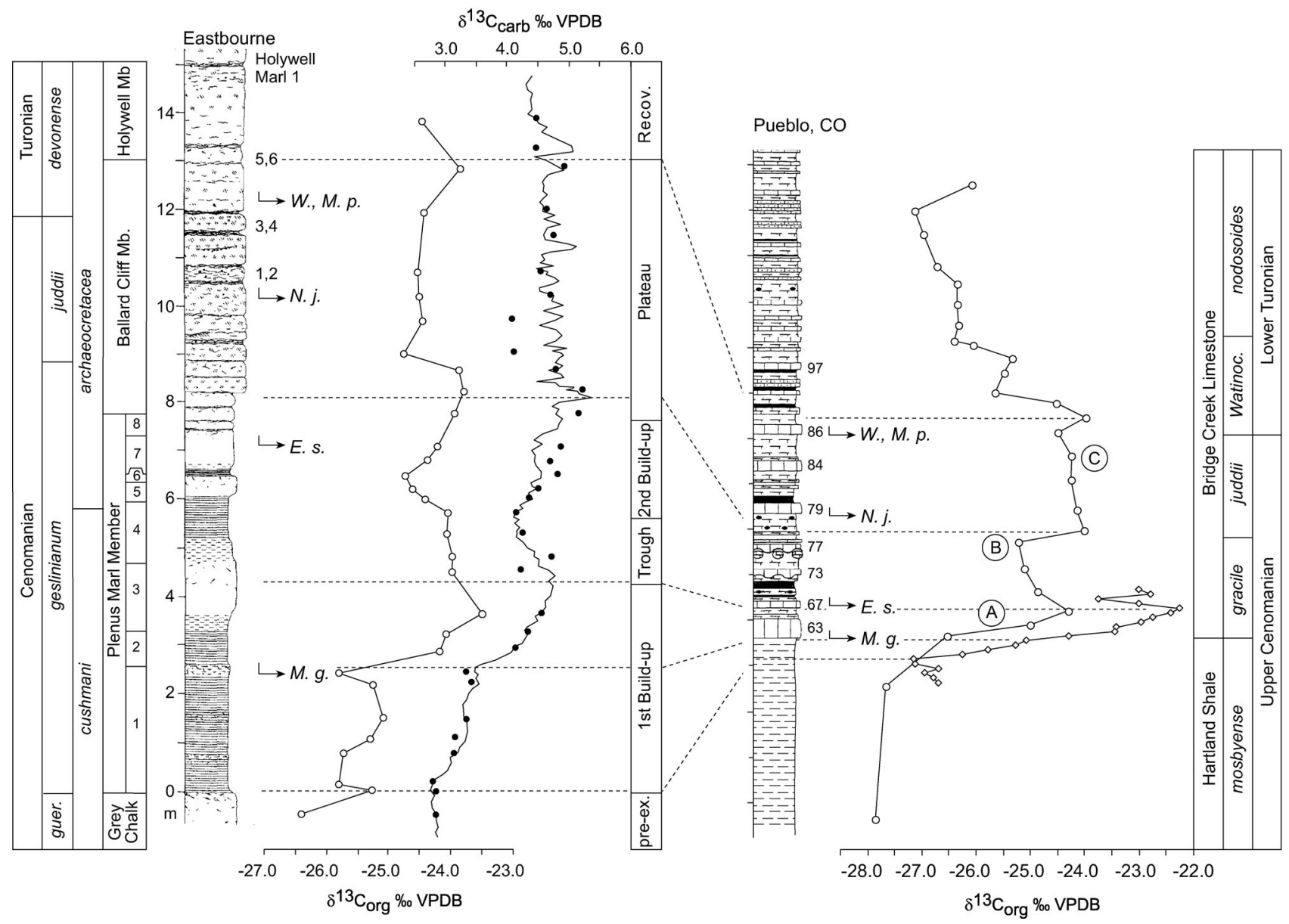

Figure 10 Stable isotope curves and correlation of the Cenomanian-Turonian boundary interval at Pueblo, Colorado and Eastbourne, Sussex, from Gale et al. (2005). The carbon isotope stratigraphy is based on Pratt \& Threlked and Gale et al. Macrofossil markers are: M.g. - first occurrence of the ammonite Metoicoceras geslinianum; E.s. - first occurrence of the ammonite Euomphaloceras septemseriatum; $N$.j. - first occurrence of the ammonite Neocardioceras juddii; W., M.p. - first occurrence of the ammonites Watinoceras spp., and the bivalve Mytiloides puebloensis. ${ }^{40} \mathrm{Ar} /{ }^{39} \mathrm{Ar}$ ages for correlative bentonites that straddle the base of the Turonian elsewhere in the U.S. Western Interior, from Obradovich (1993) are: Bed 80:93.3 $\pm 0.4 \mathrm{Ma}, 93.59 \pm 0.58 \mathrm{Ma} ; \mathrm{Bed} 88: 93.25 \pm 0.55 \mathrm{Ma}$. 
- There are no prominent facies changes across the boundary levels other than the hemipelagic limestone/marl alternations typical of rhythmically bedded Milankovitch sequences.

- The offshore pelagic Milankovitch facies is ideal for long-distance lithostratigraphic correlation, and this is enhanced by the presence of bentonite horizons.

- The presence of bentonites straddling the boundary level provides a theoretical basis for direct numerical calibration of the boundary. This has not been achieved at Pueblo owing to the thinness of the bentonite beds, but coeval bentonites elsewhere in the U.S. Western Interior allow indirect dating of the base of the Turonian Stage.

- We have no information on the magnetostratigraphy of the sequence, although it is well-known that the Turonian Stage falls within the Cretaceous Quiet Interval.

- The $\delta^{13} \mathrm{C}$ excursion across the Cenomanian-Turonian boundary interval has been recognized on a near world-wide basis in both continental and oceanic contexts. The $\delta^{13} \mathrm{Corg}$ (PDB) profile of the section including the GSSP for the base of the Turonian is ornate, with well-defined peaks and troughs that can be precisely located with respect to no less than 15 secondary biostratigraphic markers. The curve for an expanded Cenomanian-Turonian boundary interval in pelagic chalk facies at Eastbourne, Sussex, England, more than $8000 \mathrm{~km}$ east of the GSSP has a similarly ornate profile, and secondary biostratigraphic marker events occur in both sections in the same relative order, and in the same relative position to the peaks and troughs in the $\delta^{13} \mathrm{Corg}$ (PDB) curves, indicating that biostratigraphic and isotopic markers were synchronous in the two widely separated locations (Gale et al., 1993, 2005).

\section{Acknowledgements}

We thank A.S. Gale (Greenwich), G. Keller (Princeton), and S. Voigt (Cologne), for advice, and access to their unpublished data. Secretarial support from Trish McNiff (Oxford) and David Sansom (Oxford) is gratefully acknowledged.

\section{References}

Accarie, H., Emmanuel, L., Robaszynski, F., Baudin, F. Amédro, F., Caron, M. \& Deconinck, J.-F. 1996. La géochimie isotopique du carbone $\left(\delta^{13} \mathrm{C}\right)$ comme outil stratigraphique. Application à la limite Cénomanien/Turonien en Tunisie central. Comptes Rendus de l'Academie des Sciences de Paris Série 2a, 322, 579-586.

Arthur, M.A., Dean, W.E. \& Pratt, L.M. 1988. Geochemical and climatic effects of increased marine organic carbon burial at the Cenomanian/Turonian boundary. Nature 335, 714-717.

Bengtson, P. 1996. The Turonian stage and substage boundaries. Bulletin de l'Institut Royal des Sciences Naturelles de Belgique. Sciences de la Terre 66 (supplément), 69-79.

Birkelund, T., Hancock, J.M., Hart, M.B., Rawson, P.F., Remane, J., Robaszynski, F., Schmid, F. \& Surlyk, F. 1984. Cretaceous stage boundaries - proposals. Bulletin of the Geological Society of Denmark 33, 3-20.

Bralower, T.J. 1988. Calcareous nannofossil biostratigraphy and assemblages at the Cenomanian-Turonian boundary interval : implications for the origin and timing of oceanic anoxia. Palaeoceanography 3, 275-316.

Caron, M. Dall'Agnolo, S., Accarie, H., Barrera, E., Kauffman, E.G., Amédro, F., \& Robaszynski, F. (2005). High-resolution stratigraphy of the Cenomanian-Turonian boundary interval at Pueblo (USA) and Wadi Bahloul (Tunisia ): stable isotopes and bioevents correlation. Géobios. (in press)

Cobban, W.A. 1985. Ammonite record from Bridge Creek Member of Greenhorn Limestone at Pueblo Reservoir State Recreation Area, Colorado. Society of Economic Paleontologists and Mineralogists Field Trip Guidebook 4, Midyear Meeting, Golden, Colorado, 135-138.

Cobban, W.A. \& Scott, G.R. 1973. Stratigraphy and ammonite fauna of the Graneros Shale and Greenhorn Limestone near Pueblo, Colorado. United States Geological Survey Professional Paper 645, 108 pp. (1972 imprint).

Dodsworth, P. 2000. Trans-Atlantic dinoflagellate cyst stratigraphy across the Cenomanian-Turonian (Cretaceous) stage boundary. Journal of Micropalaeontology 19, 69-84.

Eicher, D.L. \& Diner, R. 1985. Foraminifera as indicators of water mass in the Cretaceous Greenhorn Sea, Western Interior. Society of Economic Paleon- tologists and Mineralogists Field Trip Guidebook 4, Midyear Meeting, Golden, Colorado, 60-7 1.

Elder, W.P. 1985. Biotic patterns across the Cenomanian Turonian extinction boundary near Pueblo, Colorado. Society of Economic Paleontologists and Mineralogists Field Trip Guidebook 4, Midyear Meeting, Golden, Colorado, 157-169.

Elder, W.P. 1987. The paleoecology of the Cenomanian-Turonian (Cretaceous) stage boundary extinctions at Black Mesa, Arizona. Palaios 2, 24-40.

Elder, W.P. 1988. Geometry of Upper Cretaceous bentonite beds; Implications about volcanic source areas and paleowind patterns, Western Interior, United States. Geology 61, 835-838.

Elder, W.P. 1991. Mytiloides hattini n. sp., a guide fossil for the base of the Turonian in the Western Interior of North America. Journal of Paleontology 65 234-241.

Elder, W.P. \& Kirkland, J.I. 1985. Stratigraphy and depositional environments of the Bridge Creek Limestone Member of the Greenhorn Limestone at Rock Canyon anticline near Pueblo, Colorado. Society of Economic Paleontologists and Mineralogists Field Trip Guidebook 4, Midyear Meeting, Golden, Colorado, 122-134.

Gale, A. S., Kennedy, W. J., \& Voigt, S., 2005. Stratigraphy of the Upper Cenomanian- Lower Turonian Chalk succession at Eastbourne, Sussex, UK: ammonites, inoceramid bivalves and stable carbon isotopes. Cretaceous Research. (in press)

Gale, A.S., Jenkyns, H.C., Kennedy, W.J. \& Corfield, R.M. 1993. Chemostratigraphy versus biostratigraphy: data from around the Cenomanian-Turonian boundary. Journal of the Geological Society of London 150, 29-32.

Hagesawa, T. 1995. Correlation of the Cenomanian/Turonian boundary between Japan and Western Interior of United States. Journal of the Geological Society of Japan 101, 2-12.

Hancock, J.M. 1984. Some possible boundary-stratotypes for the base of the Cenomanian and Turonian Stages. Bulletin of the Geological Society of Denmark 33, 123-128.

Harries, P.J. 1993. Dynamics of survival following the Cenomanian-Turonian mass extinction event. Cretaceous Research 41, 563-583.

Harries, P.J. \& Kauffman, E.G. 1990. Patterns of survival and recovery following the Cenomanian-Turonian (Late Cretaceous) mass extinction event in the Western Interior Basin, United States. in Kauffman, E.G. \& Wallister, O.H. (eds.), Lecture Notes in Earth History 03, 277-298.

Hart, M.B. \& Bigg, P.J. 1981. Anoxic events in the late Cretaceous shelf seas of northwest Europe. in Neale, J.W. \& Brasier, M.D. (eds.), Microfossils from Recent and fossil shelf seas, 117-185. Ellis Horwood Limited, Chichester.

Hattin, D.E. 1971. Widespread, synchronously deposited, burrow-mottled limestone beds in Greenhorn Limestone (Upper Cretaceous) of Kansas and southeastern Colorado. Bulletin of the American Association of Petroleum Geologists 55, 412-431.

Hattin, D.E. 1975. Stratigraphy and depositional environment of Greenhorn Limestone (Upper Cretaceous) of Kansas. Kansas University Geological Survey Bulletin 209, iii + 120 pp., 10 pls.

Jarvis, I., Carson, G., Cooper, M.K.E., Hart, M.B., Leary, P.N., Tocher, B.A., Horne, D. \& Rosenfeld, A. 1988. Microfossil assemblages and the Cenomanian-Turonian (Late Cretaceous) oceanic anoxic event. Cretaceous Research 9, 3-103.

Keller, G., Han, Q., Adatte, T.\& Burns, S., 2001. Paleoenvironment of the Cenomanian-Turonian transition at Eastbourne, England. Cretaceous Research, 22, 391-422.

Keller, G. \& Pardo, A. 2004. Biostratigraphy and Palaeoenvironments of the Cenomanian-Turonian stratotype section at Pueblo, Colorado. Marine Micropaleontology 51, 95-128.

Keller, G., Stueben, D., Zsolt, B. \& Adatte, T. 2004. Cenomanian-Turonian $\delta^{13} \mathrm{C}$, and $\delta^{18} \mathrm{O}$, sea level and salinity variations at Pueblo, Colorado. Palaeogeography, Palaeoclimatology, Palaeoecology 211, 19-43.

Kennedy, W.J. \& Cobban, W.A. 1991. Stratigraphy and interregional correlation of the Cenomanian-Turonian transition in the Western Interior of the United States near Pueblo, Colorado, a potential boundary stratotype for the base of the Turonian stage. Newsletters on Stratigraphy 24, 1-33.

Kennedy, W.J., Cobban, W.A., Elder, W.F. \& Kirkland, J.I. 1999. Lower Turonian (Upper Cretaceous) Watinoceras devonense Zone ammonite fauna in Colorado. Cretaceous Research 20, 629-639.

Kennedy, W.J., Walaszczyk, I. \& Cobban, W.A. 2000. Pueblo, Colorado, USA, Candidate Global Boundary Stratotype Section and Point for the base of the Turonian Stage of the Cretaceous and for the Middle Turonian substage, with a revision of the Inoceramidae (Bivalvia). Acta Geologica Polonica 50, 295-334

Kirkland, J.I. 1991. Lithostratigraphic and biostratigraphic framework for the Mancos Shale (Late Cenomanian to Middle Turonian) at Black Mesa, northeastern Arizona. Geological Society of America Special Paper 260, 85-111.

Kirkland, J.I. 1996. Paleontology of the Greenhorn Cyclothem (Cretaceous: Late Cenomanian to Middle Turonian) at Black Mesa, Northeastern Arizona. New Mexico Museum of Natural History and Science Bulletin 9, 131 pp. 
Kowallis, B.J., Christiansen, E.H., Deino, A.L., Kunk, M.J. \& Heaman, L.M. 1995. Age of the Cenomanian-Turonian boundary in the Western Interior of the United States. Cretaceous Research 16, 109-129.

Leckie, R.M. 1985. Foraminifera of the Cenomanian-Turonian boundary interval, Greenhorn Formation, Rock Canyon Anticline, Pueblo, Colorado. Society of Economic Paleontologists and Mineralogists Field Trip Guidebook 4 Midyear Meeting, Golden, Colorado, 139-155.

Meyers, S.R., Sageman, B.B. \& Hinnov, L.A. 2001. Integrated quantitative stratigraphy of the Cenomanian-Turonian Bridge Creek Limestone Member using evolutive harmonic analysis and stratigraphic modelling. Journal of Sedimentary Research 71, 682-644.

Obradovich, J. 1993. A Cretaceous time scale. Geological Association of Canada Special Paper 39, 379-396.

Orbigny, A. d'. 1840-1842. Paléontologie Française; Terrains Crétacés. 1. Céphalopodes. Masson, Paris, 662pp.

Orbigny, A. d'. 1842-1843. Paléontologie Française; Terrains Crétacés. 2. Gasteropodes. Masson, Paris, 456pp.

Orbigny, A. d'. 1848-1851. Paléontologie Française; Terrains Crétacés. 4. Brachiopodes. Masson, Paris, 390pp.

Orbigny, A. d'. 1850. Prodrome de Paléontologie stratigraphique universelle des animaux Mollusques et rayonnés faisant suite au cours élémentaire de Paléontologie et de Géologie stratigraphiques 2, 427 p. Masson, Paris.

Orbigny, A. d'. 1852. Cours Elementaire de Paléontologie et de Géologie Stratigraphique 2, 383-847. Masson, Paris

Orth, C.J., Attrep, M., Mao, X., Kauffman, E.G., Diner,R., \& Elder,W.P. 1988 Iridium abundance maxima in the Upper Cenomanian extinction interval Geophysical Research Letters 15, 346-349.

Paul, C.R.C., Lamolda, M.A., Mitchell, S.F., Vaziri, M.R., Goristidi, A. \& Marshall, J.D. 1999. The Cenomanian-Turonian boundary at Eastbourne (Sussex, U.K.): a proposed European reference section. Palaeogeography, Palaeoclimatology, Palaeoecology 150, 83-121.

Paul,C.R.C., Mitchell, S.,Lamolda, M. \& Gorostidi, A. 1994. The Cenomanian-Turonian boundary event in northern Spain. Geological Magazine 131, 801-817.

Pratt, L. 1981. A paleo-oceanographic interpretation of the sedimentary structures, clay minerals, and organic matter in a core of the Middle Cretaceous Greenhorn Formation near Pueblo, Colorado. Ph.D. Thesis, Princeton University, $176 \mathrm{pp}$.

Pratt, L.M. 1983. Isotopic studies on organic matter and carbonates in mid-Cretaceous strata near Pueblo, Colorado. Penrose Conference on Paleoclimates, Florissant, Colorado, Excursion Guidebook, 77-98.

Pratt, L.M. 1984. Influence of paleoenvironmental factors on preservation of organic matter in Middle Cretaceous Greenhorn Formation, Pueblo, Colorado. Bulletin of the American Association of Petroleum Geologists 68, 1146-1149.

Pratt, L.M. 1985. Isotopic studies of organic matter and carbonate in rocks of the Greenhorn marine cycle. Society of Economic Paleontologists and Mineralogists Field Trip Guidebook 4, Midyear Meeting, Golden, Colorado, 38-48.

Pratt, L.M., Arthur, M.A., Dean, W.E. \& Scholle, P.A. 1993. Paleo-oceanographic cycles and events during the Late Cretaceous in the Western Interior Seaway of North America. Geological Association of Canada Special Paper 39, 333-353

Pratt L.M., Kauffman, E.G. \& Elder, W.P. 1983. Paleontologic and geochemical resolution of the Cenomanian-Turonian (Cretaceous) extinction event in the Western Interior of North America. Geological Society of America, Abstracts with Programmes 15, 664.

Pratt, L.M., Kauffman, E.G. \& Zelt, F.B. (eds.) 1985. Fine-grained deposits and biofacies of the Cretaceous Western Interior Seaway: evidence of a cyclic sedimentary process. Society of Economic Paleontologists and Mineralogists Field Trip Guidebook 4, Midyear Meeting, Golden, Colorado, $249+26$ pp. of field reference sections.

Pratt, L.M. \& Threlkeld, C.N. 1984. Stratigraphic significance of $\delta^{13} C / \delta^{12} C$ ratios in mid Cretaceous rocks of the Western Interior. Memoir of the Canadian Society of Petroleum Geologists 9, 305-312.

Remane, J., Bassett, M.G., Cowie, J.W., Gohrbandt, K.H., Lane, H.R., Michelsen, O. \& Naiwen, W. 1996. Revised guidelines for the establishment of global chronostratigraphic standards by the International Commission on Stratigraphy (ICS). Episodes 19, 77-80.

Robaszynski, F. \& Gale, A.S. 1993. The Cenomanian-Turonian boundary - a discussion held at the final session on the colloquium on Cenomanian-Turonian events, Grenoble, 26 May 1991 (France). Cretaceous Research 14, 607-611.

Schlanger, S.O. \& Jenkyns, H.C. 1976. Cretaceous oceanic anoxic sediments: causes and consequences. Geologie en Mijnbouw 55, 179-84.

Schlanger, S.O., Arthur, M.A., Jenkyns, H.C. \& Scholle, P.A. 1987. The Cenomanian-Turonian Oceanic Anoxic Event, 1. Stratigraphy and distribution of organic carbon-rich beds and the marine excursion. Special Publication of the Geological Society of London 26, 371-99.

Scholle, P.A. \& Arthur, M.A. 1980. Carbon isotope fluctuations in Cretaceous pelagic limestones: potential stratigraphic and petroleum exploration tool. American Association of Petroleum Geologists Bulletin 64, 67-87.
Scott, G.R. 1964. Geology of the Northwest and Northeast Pueblo Quadrangles, Colorado. United States Geological Survey Miscellaneous Geological Investigations Map 1-408.

Scott, G.R. 1970. Geologic map of the Southwest and Southeast Pueblo Quadrangles, Colorado. United States Geological Survey Miscellaneous Geological Investigations Map 1-597.

Stanton, T.W 1894. The Colorado Formation and its invertebrate fauna. United States Geological Survey Bulletin 106, 288 pp. (1893 imprint).

Watkins, D.K. 1985. Biostratigraphy and paleoecology of calcareous nannofossils in the Greenhorn marine cycle. Society of Economic Paleontologists and Mineralogists Field Trip Guidebook 4, Midyear Meeting, Golden, Colorado, 151-156.

Wright, C.W.\& Kennedy, W.J. 1981. The Ammonoidea of the Plenus Marls and the Middle Chalk. Palaeontographical Society Monographs, 148 pp.

Jim Kennedy is Professor of Natural History at the University of Oxford, and Director of the University Museum of Natural History. His current areas of research are in the taxonomy, evolution, biogeography, and biostratigraphy of Cretaceous ammonite faunas from Europe, Central Asia, Africa, Pakistan, South India, Greenland and Antarctica .

Irek Walaszczyk is Professor of Earth Sciences at the University of Warsaw, where he took both his M.Sc. and Ph.D; and habilitated in 2001. He teaches regional geology and paleobiogeography. His current areas of research encompass systematics, evolution, biostratigraphy and biogeography of Late Cretaceous inoceramid bivalves from Europe, Greenland, North America South Africa, Madagascar and western Asia.

Bill Cobban is an Emeritus Scientist with the U.S. Geological Survey in Denver, U.S.A. He attended the University of Montana in Missoula, and gained his doctorate from Johns Hopkins University in 1949. His research career spans nearly 65 years; his research interests cover all aspects of the Cretaceous geology of the U.S. Western Interior, and in particular biostratigraphy, ammonite systematics, and palaeogeography.
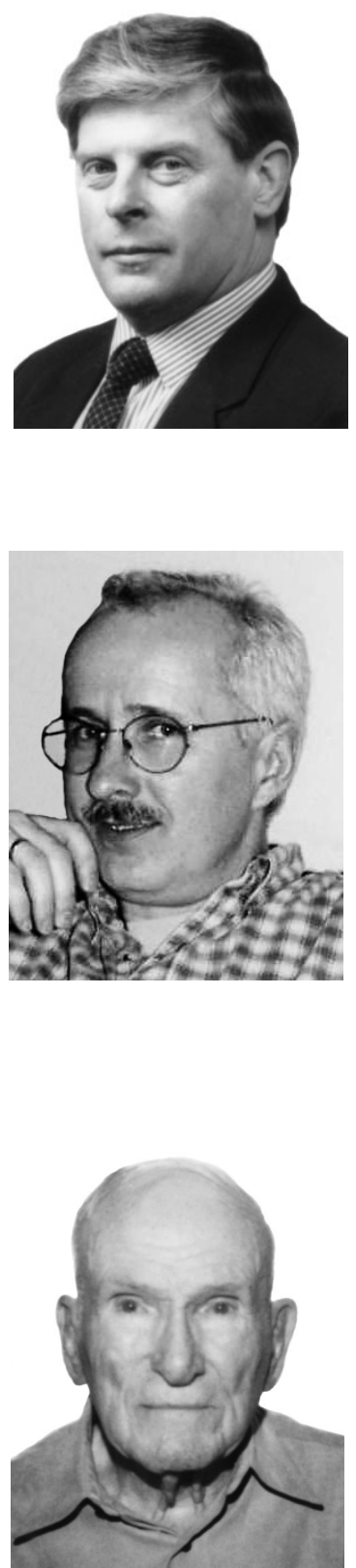